Religious Studies (2010) 46, 375-394 C Cambridge University Press 2010 doi:10.1017/S0034412509990382

\title{
A proper de jure objection to the epistemic rationality of religious belief
}

\author{
TODD R. LONG \\ Philosophy Department, California Polytechnic State University, San Luis Obispo, \\ CA 93407 \\ e-mail:tlong@calpoly.edu
}

\begin{abstract}
I answer Alvin Plantinga's challenge to provide a 'proper' de jure objection to religious belief. What I call the 'sophisticates' evidential objection' (SEO) concludes that sophisticated Christians lack epistemic justification for believing central Christian propositions. The SEO utilizes a theory of epistemic justification in the spirit of the evidentialism of Richard Feldman and Earl Conee. I defend philosophical interest in the SEO (and its underlying evidentialism) against objections from Reformed epistemology, by addressing Plantinga's criteria for a proper de jure objection, his anti-evidentialist arguments, and the relevance of 'impulsional evidence'. I argue that no result from Plantinga-style Reformed epistemology precludes the reasons I offer in favour of giving the SEO its due philosophical attention.
\end{abstract}

\section{Introduction}

There is a kind of objection concerning the epistemic rationality of religious belief that has not been adequately rebutted, much less refuted. The objection focuses on the evidence sophisticated religious believers possess with respect to propositions that are central to a religious belief system. Here I restrict my discussion primarily to Christian beliefs. Most Christians believe propositions expressed by the following: 'God - the all-powerful, all-knowing, wholly good creator of the universe - exists', 'Jesus of Nazareth was God incarnate', 'Jesus was resurrected after his death', 'I will live again after I die'. Call such propositions Christian propositions. The objection, which I call the sophisticates' evidential objection (or, SEO), concludes that the total evidence possessed by sophisticated Christians is not sufficient epistemically to justify their beliefs with respect to Christian propositions.

Reformed epistemologists, such as Alvin Plantinga, have convinced many philosophers that the kind of objection I mention fails to be 'proper' (i.e. worthy of philosophical interest) precisely because it concerns evidence. I argue that: (1) Plantinga has not shown this, and (2) the SEO satisfies Plantinga's own criteria 
for a proper de jure objection. My arguments address Plantinga's criteria for a proper de jure objection, his anti-evidentialist arguments, and the relevance of 'impulsional evidence'. I conclude with a response to the 'so-what? objection', according to which, even if all I have said is correct there is still no reason for sophisticated Christians to be troubled. My overarching conclusion is not that the SEO proves its conclusion, but rather that nothing from Plantinga-style Reformed epistemology gives us good reason not to take it seriously: it is a proper de jure objection.

\section{Presuppositions of the SEO}

The presuppositions of the kind of objection I have in mind are partly motivated by the following idea: many contemporary epistemologists, including Plantinga, analyse epistemic concepts in support of the common-sense, nonsceptical view that we have a lot of knowledge on the basis of sense perception, introspection, rational insight, reasoning, memory, and testimony. Accordingly, there is much agreement concerning examples of epistemically justified (and unjustified) belief. For instance, it is agreed that typical sensory beliefs concerning medium-size objects at close range are justified; so, if a theory implies that such beliefs are typically not justified, then that result is taken as a reason to deny the theory. Likewise, if a theory implies that human beliefs formed on the basis of tea leaf reading (or clairvoyance, or reading the stars) are routinely justified, or that the typical sensory beliefs of six-year-olds are unjustified, then such results are taken to be reasons to deny the theory. My project fits within this tradition (call it the non-sceptical tradition).

My guiding principle is that any SEO worth taking seriously will rely on a theory of epistemic justification that, from the perspective of the non-sceptical tradition, plausibly gets the correct results in all the uncontroversial cases concerning epistemically justified (and unjustified) doxastic attitudes; furthermore, that a theory of justification plausibly gets all the uncontroversial examples right is a fact that provides substantial motivation for the theory. Finally, I assume that the following principle is entirely reasonable: for any substantially motivated theory $\mathrm{T}$, unless there is an argument, utilizing non-partisan reasons, showing that $\mathrm{T}$ is explanatorily worse than another substantially motivated theory, $\mathrm{T}$ is properly motivated and thus worthy of philosophical interest. In what follows, (i) I defend a substantially motivated theory of epistemic justification against objections from Reformed epistemology, and (ii) I argue that the theory, together with additional facts about sophisticated religious believers, provides reason to think that the SEO itself is worthy of philosophical interest.

The theory I have in mind is in the spirit of the well-known evidentialist view of epistemic justification (hereafter, 'justification') developed by Richard Feldman and Earl Conee. Some notable presuppositions of the theory are as follows: first, 
the justification at issue is propositional justification rather than doxastic justification. ${ }^{1}$ Second, the justification at issue is synchronic, having to do with what one's total evidence at a particular time indicates. Third, the SEO assumes that justification comes in degrees; thus, it is consistent with the popular view that a high degree of justification is - when added to true belief and the satisfaction of a Gettier condition - sufficient for knowledge.

Fourth, although there are various standards of epistemic justification we might consider, the SEO concerns only a modest standard: an on-balance, preponderance-of-evidence standard. Accordingly, the belief attitude toward a proposition is justified for one at time $t$ only if one's total evidence at $t$, on balance, indicates the truth of the proposition. Likewise, the disbelief attitude is justified only if one's total evidence indicates the falsity of the proposition; and the suspension-of-judgement attitude is justified only if one's total evidence indicates the truth of the proposition to roughly the same extent that it indicates the falsity of the proposition. Hence, to believe $p$ when one's total evidence indicates the falsity of $p$, or when one's total evidence indicates the falsity of $p$ to roughly the same extent that it indicates the truth of $p$, is to believe against one's evidence (or, what doesn't fit with one's evidence).

Fifth, the SEO assumes a version of modest foundationalism about justification, where the justification at issue depends essentially on something mental that can plausibly be understood as a reason to believe. Because it is anti-sceptical and assumes modest foundationalism about justification, the SEO is consistent with the view that psychologically basic (i.e. non-inferred) beliefs - with respect to external world propositions (e.g. 'that is a tree'), memory propositions (e.g. 'I had coffee for breakfast'), and rational insight propositions (e.g. 'every golden trumpet is a trumpet') that are believed immediately as a response to experience - can be, and often are, justified.

Sixth, 'sophisticated Christians' is taken to mean those Christians who are (i) smart, reflective, and well-educated; (ii) aware of the problem of evil, facts about religious diversity, and various arguments that count against the truth of Christian propositions; and (iii) aware of many very smart people who either suspend judgement on or disbelieve Christian propositions. ${ }^{2}$

The SEO assumes what I call the 'evidence-justification principle':

evidence-justification principle If a person $\mathrm{S}$ is epistemically justified in believing a proposition $p$ at time $t$, then S's total evidence supports $p$ at $t$ and fails to support $\sim p$ at $t .^{3}$

The evidence-justification principle is entailed by what I take to specify the central idea of synchronic epistemic evidentialism (call it 'general evidentialism' or ' GE'):

general evidentialism (GE) S is epistemically justified in believing a proposition $p$ at time $t$ iff $p$ is supported by S's total evidence at $t .^{4}$ 
The SEO, then, is consistent with, and motivated by, the traditional view that having evidence is of great epistemic importance. ${ }^{5}$

By the 'evidence' required for justification, I am thinking of the 'mentalism' (or, 'mind internalism') endorsed by Conee and Feldman (2004), according to which all the factors that contribute to justification are in a person's mind. ${ }^{6}$ Evidence consists only of mental states, events, and conditions that are indications of truth. The SEO assumes what can usefully be termed long evidence, which construes the evidence one possesses broadly and deeply: all experiences that plausibly indicate truths count as evidence. ${ }^{7}$ Accordingly, one's evidence at a time includes one's perceptual experiences, introspective experiences, memorial experiences, 'seeing-the-truth' experiences, reasoning experiences, and any other kinds of mental experiences that plausibly indicate truths, as well as stored experiences that fall under any of the categories listed above. ${ }^{8}$ One's 'total evidence' consists of all one's occurrent and stored long evidence.

These suppositions taken together (with a few others to be discussed) constitute the view I will refer to as long evidentialism. It is intended not to be novel, but to reflect (from the perspective of the non-sceptical tradition) our uncontroversial judgements about examples of justified (and unjustified) belief. It is thus substantially motivated and at least prima facie plausible as properly motivated. Later, I provide positive reasons to think that the SEO is worthy of interest; but, first, I do some ground clearing pertaining to work from Reformed epistemology, for some of it calls into question my claim that long evidentialism is properly motivated.

\section{Responses from Plantinga-style reformed epistemology}

The work of Reformed epistemologists such as Plantinga suggests that any objection along the line of the SEO is misguided or irrelevant. Plantinga has argued that one's having evidence with respect to a proposition $p$ is not necessary for one's being epistemically justified in believing $p$, and that one's having evidence with respect to $p$ is irrelevant or unnecessary for one's belief that $p$ to be epistemically rational. Plantinga has typically drawn such conclusions on the basis of objections to what he calls 'evidentialism', and he has provided many negative critical assessments of the views of a wide variety of well-known epistemologists who think of themselves as evidentialists. This pattern gets an update in his mature Warranted Christian Belief [hereafter, WCB or (2000)] where Plantinga argues that the only proper objection to the rationality of religious belief is the 'Freud \& Marx objection' (which does not call into question the evidence religious believers have). Given these data, and the fact that Plantinga is the central figure in Reformed epistemology, it seems that the basic thrust of Reformed epistemology's response to the SEO would be this: the objection assumes a central tenet of evidentialism (i.e. the evidence-justification 
principle); but, one's having evidence is either (a) unnecessary for one to be epistemically justified in believing $p$, or (b) inessential to whether one's doxastic attitude toward $p$ is rational; hence, the objection fails to reveal any problem for sophisticated Christians.

There are subtle taxonomic details to sort through. A clever Reformed epistemologist might exploit such subtleties to deny both (a) and (b) above; for instance, one might use Plantinga's notion of 'impulsional evidence' - together with insights from Norman Kretzmann's compelling argument that Plantinga's anti-evidentialist arguments apply only to narrow, implausible construals of evidentialism - in order to argue that Plantinga is an evidentialist! ${ }^{9}$ But, as I argue in the section on 'Plantingan evidentialism', a Plantinga-motivated evidentialism is far too epistemically anaemic to block the force of the SEO or show that it is improper.

\section{Plantinga's project in Warranted Christian Belief}

Plantinga's goal in WCB is to show how it is possible for Christian belief to be epistemically rational. He argues that the 'extended a/c model' reveals that it is epistemically possible for Christian beliefs to satisfy the conditions of his own theory of epistemic warrant.$^{10}$ He seeks to motivate our interest in his theory by arguing that the only proper de jure objection calls into question the Plantingan warrant of Christian belief. In its broadest form, the de jure objection goes like this: whether Christian beliefs are true or false, such beliefs are 'irrational or unreasonable or unjustified or in some other way properly subject to invidious epistemic criticism' (Plantinga (2000), 167). Plantinga whittles away various particular de jure objections, settling finally on what he takes to be the only proper one (i.e. the Freud \& Marx objection). ${ }^{11}$ He then argues that any version of that objection assumes the falsity of Christian beliefs. If he is successful, then since what he calls a 'de facto objection' assumes that Christian belief is false, Plantinga will have shown that there is no proper de jure challenge that is independent of a de facto challenge. ${ }^{12}$ The relevant result is that there is no cogent de jure objection at all. This implies that the SEO is also no good.

\section{Plantinga on de jure objections}

Well before the publication of WCB, William Alston (1995), 68-69, revealed the implausibility of thinking that there is only one proper de jure objection. Undaunted by the criticism, Plantinga devised in WCB a slightly new strategy for convincing us: first, count as 'improper' any de jure objection that has some of the following properties: lacking viability (Plantinga (2000), 169), lacking sensibility (ibid.), being trivial (ibid., 137), and not being relevant (ibid.) ; ${ }^{13}$ second, trot out several de jure objections and argue that they are easily refuted or possess some of the improper-making properties; third, leave showing the improperness 
of any other de jure objections as homework for the rest of us (ibid., 104); and fourth, conclude that the Freud \& Marx objection is the only proper de jure objection.

Although $W C B$ has many excellent qualities, the strategy Plantinga uses to motivate our interest in his epistemic theory is not among them. The fourth step is especially puzzling in light of his claim that the Freud \& Marx objection is futile: 'We can ... see the futility of the [Freud \& Marx] complaint', he says, 'once we see how theistic belief might have warrant' (Plantinga (2000), 168). But, an objection's being futile surely sounds as bad as the other improper-making properties. So why favour the Freud \& Marx objection?

Although I find no good reason to privilege the Freud \& Marx objection, Plantinga has a practical reason to do so, since that objection happens to be the very one for which his own theory of warrant is relevant. But, from the fact that someone has a practical reason to privilege an objection, it does not follow that we have an epistemic reason to do so. Even if taking a lot of effort to rebut is required for something to be a proper de jure objection, the SEO suffices. ${ }^{14}$ Lest we draw this conclusion hastily, let us consider Plantinga's arguments for the conclusion that there is no proper evidentialist objection to the epistemic justification of Christian belief.

\section{Plantinga on evidentialism and epistemic justification}

In $W C B$ (as elsewhere) Plantinga's commentary on epistemic justification focuses on what he calls the 'classical picture', which is comprised of three elements: a deontological view of epistemic justification, evidentialism, and classical foundationalism..$^{15}$ Plantinga construes 'evidentialism' such that something counts as a person S's evidence $\mathrm{E}$ with respect to a proposition $p$ only if $\mathrm{E}$ is propositional and is relied on explicitly by $S$ in an inference. And he claims that evidentialism just is a deontological theory (having to do with praiseworthiness and blameworthiness) that gets its rationale from classical foundationalism.

Although there are examples of such views, the long evidentialism implicit in the SEO is not among them. As I have said, long evidentialism is a modest foundationalist view. Since it is an evidentialist view, it entails that there is evidence in all cases of justified basic belief; hence, given our anti-sceptical assumption, long evidentialism implies that there are justified basic beliefs which do not get their justification via psychological inference from other believed propositions. Furthermore, long evidentialism does not get its rationale from deontological considerations having to do with praise and blame; indeed, I am convinced that there is no good argument from that kind of deontology to epistemic internalism (of which long evidentialism is a species). ${ }^{16}$ From what, then, does long evidentialism get its rationale? It gets it (in part) from the fact that it does better than any other theory at preserving all the uncontroversial judgements that are part of the non-sceptical tradition. Although I will not argue for 
that conclusion here, I will defend long evidentialism against Plantinga's antievidentialist arguments.

Since long evidentialism is not a theory that falls under the 'classical picture', the SEO is immune to all of Plantinga's arguments that trade on a deontological notion of epistemic justification, or classical foundationalism, or Plantinga's construal of 'evidentialism'. Indeed, only one passage in WCB so much as suggests an objection applicable to long evidentialism:

\begin{abstract}
Consider memory. You remember what you had for lunch: lentil soup and a doughnut. This belief isn't based on propositional evidence. You don't infer it from other things you know or believe, such things, perhaps, as your knowledge that you always have a doughnut and lentil soup for lunch, or your knowledge that it is now shortly after lunchtime and there are doughnut crumbs on your desk and an empty plastic soup dish in your trash. ... But it also isn't based on an experience. At any rate, it is clear that memory beliefs are not based on anything like sensuous experience or phenomenal imagery. There may be a bit of such imagery present (a fragmentary and partial image of a doughnut or a bowl, perhaps), but you certainly don't form the belief on the basis of that image. It is clear that you could remember without having that imagery - or, indeed, any other imagery. So the imagery isn't necessary. It is also insufficient; you could also have that imagery without remembering. The reason is that the imagery that goes with imagining that you had a doughnut and lentil soup for lunch, or entertaining the proposition that you did, is indistinguishable (at least in my own case) from the imagery that goes with remembering that you had a doughnut and lentil soup for lunch. And even if you do have fairly explicit phenomenal imagery in connection with this memory, you surely don't know that it was lentil soup on the basis of that imagery; the image isn't nearly clear, detailed, and explicit enough to enable you to distinguish it from, for example, imagery of pea soup, or bean soup, or many other kinds of soup. (Plantinga (2000), 105-106)
\end{abstract}

To his familiar (and, I think, correct) point that we do not typically form a memory belief via a conscious inference from propositions about how things seem to us, Plantinga here adds a stronger claim: 'But it also isn't based on an experience' (ibid.). This gives us the seed of an objection even to the general version of evidentialism: if there are epistemically rational beliefs that are not related in any epistemic way to an experience, then there is no principled reason for maintaining that all epistemically justified beliefs are supported by evidence.

However, Plantinga does not really think that there are any epistemically rational beliefs disconnected from experience. Notice the qualification: 'At any rate, it is clear that memory beliefs are not based on anything like sensuous experience or phenomenal imagery' (ibid., 106). Let us take care: it is one thing to say that a memory belief is not based on an experience, but it is another thing to say that a memory belief is not based on sensuous experience or phenomenal imagery. It may be that epistemically rational memory and a priori beliefs need not be based on sensuous experience or phenomenal imagery, but Plantinga does not show, nor does he believe, that experience plays no role in determining the 
epistemic status of memory and a priori beliefs. To clarify, consider one more passage where Plantinga compares religious beliefs to memory beliefs and a priori beliefs:

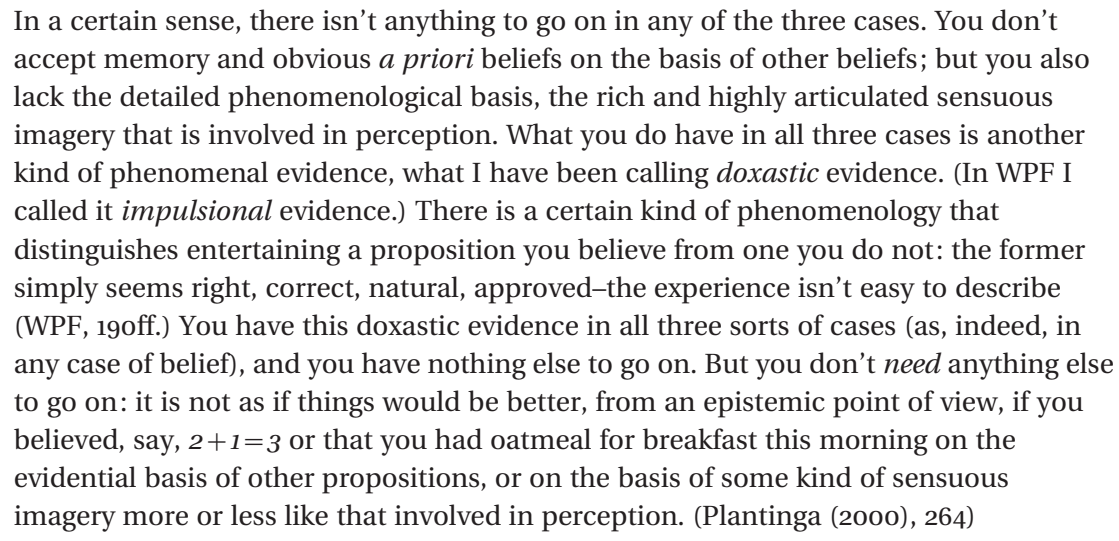

Based on this passage, a case against GE and long evidentialism might go as follows: with respect to perceptual beliefs such as visual beliefs, there is the presence of experiential evidence in the form of phenomenal qualities: things looking a certain way to you can legitimately be construed as supporting evidence for your visual beliefs; however, in the case of memory and a priori beliefs, there need be no such thing as the way things look to you (e.g. no images) that play a role in your forming the beliefs that you do; hence, you have no evidence for memory beliefs and a priori beliefs.

However, if this were taken to be an objection to GE or long evidentialism, then it would fail. From the fact that no highly articulated sensuous imagery is present with respect to an intuitively justified believed proposition, it does not follow that there is no evidence. Consider an elementary a priori belief formed as a response to an experience that is sometimes described as 'seeing the truth'. It is very plausible that such an experience is characterized by awareness of the truthmaking constituents of the relevant proposition and relations among those constituents. ${ }^{17}$ So, it is very plausible that having the peculiar experience constituting 'seeing the truth' just is good evidence for the proposition believed.

Something similar goes for occurrent memory beliefs, which are formed as a response to memorial experience: whether or not the experience includes sensory imagery, it surely has a looking-back-in-time quality to it, for, if it lacked such a quality, it would not give rise to what qualifies as an occurrent memory belief. ${ }^{18}$ Furthermore, the experience represents some particular state of affairs rather than others. The looking-back-in-time quality and the representative content involved are plausibly evidence for something's having occurred in the past; for, that kind of experience just is the kind that indicates something's having happened in the past. Such justification is defeasible, but unless it is defeated by 
other evidence one possesses, it is plausible that the peculiar experience that goes with remembering just is a good reason (i.e. good evidence) for the relevant proposition believed.

I conclude that reflection on the passage reveals nothing to impugn long evidentialism. In every instance of an epistemically rational belief that Plantinga discusses, there is some experience that serves as the ground or basis or trigger for that belief. Moreover, in every uncontroversial case of epistemically rational belief, there is an experience (or set of experiences) that can plausibly be regarded as indicating the truth of the proposition believed. So, nothing along the lines under discussion provides reason to deny long evidentialism. These considerations may help to explain Norman Kretzmann's claim that, were it not for Plantinga's 'artificially narrow notion of evidence when characterizing evidentialism or his own position ... he would not be an anti-evidentialist' (Kretzmann (1992), 24).

\section{Plantingan evidentialism}

Might we argue against the SEO by adapting some of Plantinga's epistemic views into an evidentialist framework amenable to long evidentialism? In particular, can we get a Plantingan understanding of the evidence that long evidentialism appeals to in order to argue that sophisticates' Christian beliefs are typically justified? Two ideas come to mind: Plantinga's proper functionalism and what he calls 'impulsional evidence'.

\section{Evidentialism and proper function}

Although we cannot easily understand the supports relation mentioned in GE in terms of proper function (since GE pertains to propositional justification), perhaps we can understand, in terms of proper function, a long-evidentialistfriendly relation involved in doxastic justification. In one place Feldman \& Conee (2004, 83) characterize evidentialism as follows: 'Doxastic attitude D toward proposition $\mathrm{p}$ is epistemically justified for $\mathrm{S}$ at $\mathrm{t}$ if and only if having $\mathrm{D}$ toward $\mathrm{p}$ fits the evidence $S$ has at $t$ '. Perhaps the epistemic fittingness appealed to can be explained in terms of proper function. As I have said, Plantinga thinks that, in every case of epistemically rational belief, there is an experience that serves as a ground or basis or trigger for that belief. The epistemic fittingness under discussion works nicely when we consider the experience to involve a non-inferential mental state that very plausibly indicates the truth of a proposition due to the fact that it pretty closely reflects or mirrors the relevant proposition: intuitively, a hand-like visual experience indicates that 'that is a hand'; a voice-like auditory experience indicates that 'someone is talking'; a looking-back-in-time experience of a certain sort indicates that 'I had coffee for breakfast'; a certain seeing-the-truth experience indicates that ' $2+3=5$ ', etc. ${ }^{19}$ There is some plausibility in thinking that we are exhibiting epistemic proper function in 
these cases when we form the relevant beliefs on the basis of the evidence described.

The trouble is that Plantinga claims that some experiences serve as the causal triggers for rational beliefs when those experiences do not closely reflect or mirror the relevant proposition. For instance, Plantinga says that one's experience of looking at a lovely flower can trigger the sensus divinitatis to produce a belief such as 'God made all this'. The experience is of a flower, not of God; but, the belief is about God. Plantinga has done an admirable job of explaining how it is possible for that belief to be the result of proper function, but it does not follow that the belief fits the evidence at issue (by hypothesis, the flower-experience doesn't look like God).$^{20}$ What seems entirely natural is that beliefs with respect to propositions such as 'that is a flower' fit the evidence, because it is plausible that the evidence is an indication of the truth of such propositions. But, it seems ad hoc to think that such evidence indicates the truth of the theistic proposition.

I am open to the possibility that the doxastic epistemic fittingness relation can be understood in terms of proper function, but it seems to me that any plausible view along that line will deny that an experience's mere triggering of a belief, even when the proposition believed is true, and even when it is caused by a reliable belief-producing mechanism, counts as an indication to the person that the proposition believed is true. But, what counts as an indication of truth to the person just is what the evidential supports relation pertains to, and this is a nonnegotiable component of long evidentialism. This is no objectionably dogmatic point, since it is Plantinga's judgement of the example that is controversial. So, unless there is some good reason to think that the mental experience as of, say, seeing a flower is itself an indication of the truth of a theistic proposition, there seems to be little hope of adapting Plantinga's particular views about proper function to long evidentialism in a way that shows that the SEO fails. ${ }^{21}$

\section{Evidentialism and 'impulsional evidence'}

As the quotation above indicates, Plantinga says that there is 'impulsional evidence' in all cases of belief. Perhaps reflection on this fact shows that the SEO is not worthy of attention. Saying that the impulsional evidence for a sensory, memorial, or a priori proposition makes the proposition seem right, Plantinga claims that such evidence is good enough for belief, from the epistemic point of view; indeed, he says you don't need anything else to go on. One might think, then, that this result lends support to long evidentialism; ${ }^{22}$ moreover, because there is impulsional evidence in all cases of belief, and sophisticated Christians have lots of Christian beliefs, one might claim that Christian propositions are supported by such evidence.

Nevertheless, there are reasons to doubt that 'impulsional evidence' actually does any interesting evidential work. One reason concerns the nature of impulsional evidence. In Warrant and Proper Function (1993a)-where Plantinga 
discusses in detail the relation between seeing the truth of a proposition (e.g. 'if Sam is happy, then someone is happy') and impulsional evidence - he writes:

You see that the proposition is true: and that involves an inclination or impulse toward believing the proposition-an inclination that is either experienced or such that it can be brought to consciousness by paying attention to it. Perhaps we should say instead that the proposition in question has a sort of attractiveness, or perhaps inevitableness about it, or perhaps a sort of perceived fittingness; the phenomenology is hard to describe, but familiar to us all. (Plantinga (1993a), 191)

Although the impulsion to believe may be stronger with respect to obvious a priori beliefs than with other kinds of belief, the general idea is supposed to apply in all cases of belief: (1) one's impulsion to believe (i.e. the experience of the impulse alone) causes the proposition to seem true to one; thus, (2) 'impulsional evidence' is evidence for the proposition believed.

But, the inference from (1) to (2) is doubtful. Note first that feeling impelled to believe a proposition is not always epistemic. A proposition such as 'everything will turn out all right' may be so attractive to a person in a desperate situation - because it is reassuring - that the person feels impelled to believe it. But its being reassuring does not itself provide any epistemic reason to believe the proposition. An epistemic reason to believe a proposition just is an indication that the proposition is true. The desperate-situation example shows that one may feel impelled to believe a proposition even if one has no epistemic reason to believe it. So, if one does have an epistemic reason to believe a proposition, that reason is something other than the impulsion to believe. The upshot is that an impulsion to believe is not itself evidence.

Second, reflection suggests that Plantinga has backward the explanatory relation between seeing the truth and feeling impelled to believe. One doesn't see the truth of a proposition because (in part) one feels impelled to believe it, but rather one feels impelled to believe the proposition because one sees its truth. Seeing that a proposition is true surely counts as an epistemic reason for believing the proposition, since the experience of seeing the truth of a proposition indicates to one that it is true, but feeling impelled to believe is, by itself, no epistemic reason at all for believing the proposition. ${ }^{23}$ Similarly, one's having a visual experience as of a tree might cause one to feel impelled to believe that 'that is a tree', but for the same reasons as mentioned above, it does not follow, nor is it plausible, that the feeling of impulsion itself indicates that 'that is a tree'.

In any case, the fact that there is 'impulsional evidence' in all instances of belief - no matter how irrational - reveals that having impulsional evidence is far too anaemic to do much epistemological work. Furthermore, reflection on the ubiquitous nature of 'impulsional evidence' reveals that any evidentialist view taking 'impulsional evidence' to be sufficient for justification runs foul of the non-sceptical tradition, which has its plausibility in part because it acknowledges 
that not all beliefs are justified. I conclude that facts about 'impulsional evidence' provide no reason to think that Plantinga's views afford us plausible ways to use long evidentialism against the SEO.

\section{Does the SEO assume that Christian propositions are false?}

In $W C B$, Plantinga says that there is no proper de jure objection that does not assume the falsity of theistic belief: 'There aren't any de jure criticisms that are sensible when conjoined with the truth of theistic belief; all of them either fail right from the start ... or else really presuppose that theism is false' (Plantinga (2000), 191). Is the SEO committed to the falsity of theism or Christianity? No. I can demonstrate this by commenting on WCB's overarching argument, which is as follows: if the main lines of Christianity are true, then God would want persons to have warranted beliefs with respect to Christian propositions; and, if the consequent of the previous sentence is true, then very probably paradigmatic Christian beliefs are warranted; so, if the main lines of Christianity are true, then very probably paradigmatic Christian beliefs are warranted (and thus epistemically rational). In a structurally identical argument applied to the kind of epistemic justification at issue in the SEO, the first premise would be this: If the main lines of Christianity are true, then God would want persons to have epistemically justified beliefs with respect to Christian propositions.

There are reasons, even reasons internal to a popular view about Christian faith, for denying that first premise. No doubt, if the Christian story is true, then God would want persons to have particular affections toward God and others, to engage in particular actions or kinds of actions, and to have particular beliefs, including true ones about the main lines of Christianity, required to aid one in living a faithful Christian life. But, it does not follow that God would want persons to have epistemically justified beliefs with respect to Christian propositions. Indeed, according to a leading notion of faith as it pertains to belief, belief by faith goes beyond, so to speak, the evidence we have. According to this view, which seems to be supported by various passages in scripture, it is a sign of mature faith that one has confident belief about some matters even when the evidence is not suitably impressive. The idea is that there is something religiously valuable about having some beliefs that do not fit with what one's evidence indicates.

In fact, there is a wide range of views about faith along this line. At one extreme is the radical Kierkegaardian view ('I believe because it is absurd') $;^{24}$ according to a popular interpretation, this view makes faith out to involve believing what is plainly inconsistent with one's evidence. Less radical (and, I think, more plausible) views involve the idea that faith produces belief even when one's evidence with respect to the proposition believed no more indicates the truth of the proposition than it indicates its falsity. ${ }^{25}$ Implicit in all such views is the idea that 
faith is valuable because it produces the kind of confidence in the main lines of Christianity that is not so sensitive to the vicissitudes of one's ever-changing evidence base; and, partly for that reason, one's living a life of faith - which crucially involves factors intimately related to one's beliefs (e.g. one's affections, desires, and actions) - need not be ruined by every epistemic challenge that comes along. Accordingly, faith characteristically produces true beliefs that aid one in living a good Christian life, but it does not follow that faith characteristically produces epistemically justified belief. Such a view is thus consistent with the thesis that faith characteristically produces true, but epistemically unjustified, belief. Reflection on the religious plausibility of the view reveals that the SEO is not committed to the falsity of Christian propositions; for, even if the SEO proves its conclusion, it is possible that Christian propositions are true. Hence, the SEO is sensible when conjoined with the truth of Christian belief.

\section{Why the SEO is worthy of philosophical interest}

It is surely not obvious that the total evidence of sophisticated Christians indicates the truth of Christian propositions. Long evidentialism is consistent with the view that our psychologically basic perceptual beliefs, memory beliefs, and a priori beliefs can be, and typically are, epistemically justified. But, it does not follow that a psychologically basic Christian belief is epistemically justified. If it is, then that will be partly, but crucially on long evidentialism, in virtue of a person's being in a non-inferential mental state that indicates the truth of the relevant Christian proposition. So, to argue that such a state of affairs obtains, one needs to explain how a non-inferential mental state can indicate the truth of such a proposition.

Although that is no easy task, another strikes me as even more difficult: explain why some putative defeaters for Christian propositions (or for the reasons sophisticates have for believing such propositions) - that sophisticates are well aware of - are not actual defeaters. Those worth taking seriously include some arguments from evil, some arguments from religious (and non-religious) diversity, knowledge of epistemic peers who believe propositions inconsistent with Christian propositions, and arguments for the conclusion that religious experiences are best explained not by the putative truth-makers of Christian propositions but by non-supernatural causes. And, depending on how much rational strength one's objections have against the individual putative defeaters, one might still need to explain why the totality of the putative defeaters do not constitute epistemic defeat. On the other hand, if one attempts the strategy of arguing that sophisticated Christians are justified in believing Christian propositions on the basis of justified inferences, then one has the difficult task of explaining what sort of inferences are sufficient in light of knowledge of the putative defeaters. ${ }^{26}$ 


\section{The so-what? objection}

If the conclusion of the SEO does not imply that Christians are blameworthy for their Christian beliefs, and if it is plausible to understand religious faith in such a way that believing against one's evidence can be a virtue, then why worry about the SEO? Even if everything I have said is true, so what? ${ }^{27}$ Why should sophisticated Christians be concerned about having doxastic attitudes that go against their evidence?

What's bad about believing against one's evidence?

Although I am not myself an evidentialist objector to the rationality of Christian beliefs, ${ }^{28}$ I think that there are plausible evidentialist-friendly answers to the so-what question. For one thing, believing what one's evidence supports at a time is necessary for having knowledge at that time, and knowledge is intrinsically valuable; so, by believing what one's evidence does not support, one fails to have something intrinsically valuable.

But, this is not a fully satisfactory answer to our question. One reason is that one can fail to have knowledge even when one believes a proposition that one's total evidence massively (but not perfectly) supports. ${ }^{29}$ Another reason concerns the doxastic attitude of suspending judgement. I take it that any plausible view of epistemic rationality implies that suspending judgement can be the epistemically rational attitude to take toward a proposition at a time. But one fails to have knowledge every time one suspends judgement. Such considerations reveal a more important reason that it is bad to believe against one's evidence: doing so prevents one from having an epistemically rational attitude at the very time at issue.

Epistemic rationality is an evaluative concept, which has to do with satisfaction of an intellectual standard at a time, a standard the satisfying of which constitutes epistemic value with respect to rational enquiry at that time. ${ }^{30}$ That standard just is having a doxastic attitude that is supported by one's evidence. There is a simple but powerful argument for this. 'Rational' means 'of or based on reasoning or reason'. ${ }^{31}$ Although there are various kinds of reason, one has an epistemic reason at a time only when one has an indication of the truth of a proposition at that time. And any indication of the truth of a proposition to a person is very plausibly some evidence the person has with respect to that proposition. So, epistemic rationality at a time is a matter of one's evidence that a proposition is true. In failing to have the doxastic attitude that fits one's evidence at a time, one fails to gain something of epistemic value.

Furthermore, intuitively the epistemic value of rationality is greater than the epistemic value of truth. It is frequently said that lucky true beliefs are not particularly valuable epistemically. Virtually everyone agrees that you are not doing so well epistemically in luckily believing a truth: the common view is that you're doing much better epistemically by rationally believing. So, inasmuch as 
epistemic rationality at a time is a matter of believing what one's evidence supports at that time, believing against one's evidence is a bad thing with respect to what is plausibly the more valuable epistemic good.

So, believing what one's evidence does not support exhibits a kind of intellectual failure. This is because, other things being equal, it is intellectually better to have an epistemically rational doxastic attitude toward a proposition than an epistemically irrational doxastic attitude. I take it that this is true regardless of what plausibly explains 'intellectually better' ${ }^{32}$ The upshot is that those who have doxastic attitudes that do not fit their evidence fail, with respect to those attitudes, to satisfy the standard of epistemic excellence that characterizes well-done rational enquiry. That is what is bad about believing without, or against one's, evidence.

There may be a special reason that believing against one's evidence is bad for sophisticated Christians. St Anselm's motto, 'Faith Seeking Understanding', speaks to an aim of importance to typical sophisticated Christians, for it is also the motto of the contemporary Society of Christian Philosophers. The phrase contains ambiguities, but surely it is often taken to express a desire to discover how the central Christian doctrines are consonant with the aim of rational enquiry. Considered in light of much contemporary work in philosophical theology, it is clear that 'faith seeking understanding' is often taken to express more than merely understanding the meanings of Christian doctrines and relations among them: it also involves understanding how religious belief is rational. On the present proposal that the aim of rational enquiry involves believing in accordance with one's evidence, believing against one's evidence can be in tension with satisfying one's goal of understanding one's faith.

\section{Epistemic rationality and blameworthiness}

In any case, it does not follow that people who have doxastic attitudes that go against their evidence deserve blame for those attitudes. The most fundamental reason for this is that our doxastic attitudes are not under the kind of direct voluntary control required for us to be responsible for them. ${ }^{33}$ We may well have direct voluntary control over some of the actions that bear on which beliefs we will have-paying close attention to our evidence, enacting policies about virtuous evidence acquisition, and so on - but those are actions, not beliefs. One might deserve praise or blame for such actions, but since one's doxastic attitudes are not under one's immediate voluntary control, one does not deserve praise or blame for them.

Another reason has to do with the way that one's beliefs at a time can positively affect one's future actions and future beliefs. It could be a contingent fact that one will gain an epistemically rational (and perhaps prudentially or morally beneficial) belief that $q$ in the future only if one now believes a proposition $p$ that is not supported by one's current total evidence. To extend an example by James 
$(2003,526)$, suppose that you are stuck on a mountainside in a blinding blizzard, and you realize that you won't survive the night by staying where you are. Fumbling your way along a ledge, you come to an impassable wall. You consider jumping, in the hope that you'll land safely below and find shelter, but you lack the nerve to jump. So, you convince yourself, by means of a pep talk, to believe $p$ : I'll land safely if I jump. However, since you have little or no indication that $p$ is true (and you remember that the general region you're in is mostly sheer), your total evidence doesn't support $p$. Nevertheless, emboldened by your belief that $p$, you jump, landing safely ten feet below, where you find a cave that provides shelter for the night. Next morning you wake up believing $q$ : I've survived the night and have a good chance of getting off the mountain alive, on the basis of perception and your mountaineering knowledge.

So, here is a case in which you have an epistemically rational belief that $q$, which you would not have had if you had not earlier believed $p$, which was not then supported by your total evidence. It seems clear that you do not deserve blame for believing $p$; after all, had you not believed $p$, you would neither have rationally believed $q$ nor have survived. Reflection on examples like this reveals that the kind of synchronic rationality that the SEO focuses on can have instrumental value (or disvalue) for various kinds of diachronic rationality, epistemic and otherwise. ${ }^{34}$

I think such considerations are significant for right thinking about the kind of belief that is involved in what is called religious faith. What I have said on behalf of long evidentialism is consistent with the possibility that Christians' irrationally believing Christian propositions at some particular time will play a crucial causal role in their rationally believing Christian propositions at a later time. Perhaps this point is relevant to an aim expressed in 'faith seeking understanding', for it is credible that some understanding comes only by way of prior faith..$^{35}$

Does this lessen philosophical interest in epistemic rationality at a time, which the SEO focuses upon? I should think not. For even if Christians' irrational beliefs can have instrumental epistemic value with respect to some future beliefs, their having synchronic epistemically rational beliefs whenever they do so will be in virtue of their having evidence that, on balance, supports those propositions; and, this is precisely the feature that the SEO focuses on.

Still, given my view about faith, there can be times in a sophisticate's life in which two different doxastic goods are at odds. For instance, one can have the religious doxastic good of believing a proposition against one's evidence and thereby lack the epistemic good of believing in accord with one's evidence, and vice versa. So, even if a sophisticated Christian were convinced that the SEO is successful, she might not be so worried about it because she thinks that she is often gaining a more important good. The SEO is entirely neutral about that. But, she might nevertheless find troubling a question in the spirit of the SEO: what 
reason do you have to think that you are gaining a more important good by believing against your evidence?

\section{Conclusion}

I conclude that Plantinga's arguments on behalf of Reformed epistemology do not provide good reason to think that the SEO is improper; thus, it is philosophically worthwhile to consider whether the most plausible, fully articulated version of the SEO is a good objection to the epistemic rationality of Christian belief. Such considerations will require much thought about the total evidence sophisticated Christians have, and this will surely require much more work than has been done about how religious experiences can provide evidential support for Christian propositions. ${ }^{36}$ Perhaps, in the future, the objection will be shown to be as futile as the Freud \& Marx objection. But, is it not a proper objection $?^{37}$

\section{References}

Alston, W. (1991) Perceiving God: The Epistemology of Religious Experience (Ithaca NY: Cornell University Press).

(1985) 'Plantinga's epistemology of religious belief', in J. E. TOMBERLIN \& P. van INWAGEN (eds) Alvin Plantinga (Dordrecht: D. Reidel), 289-311.

(1995) 'Reply to critics', Journal of Philosophical Research, 20, 67-81.

AudI, R. (1993) 'The foundationalism-coherentism controversy: hardened stereotypes and overlapping theories', in idem (ed.) The Structure of Justification (Cambridge: Cambridge University Press), 117-164.

Bergmann, M. (2006) Justification without Awareness: A Defense of Epistemic Externalism (Oxford: Oxford University Press).

Cohen, S. (1984) 'Justification and truth', Philosophical Studies, 46, 279-295.

Conee, E. (1992) 'The truth connection', Philosophy and Phenomenological Research, 52, 657-669. (1998) 'Seeing the truth', Philosophy and Phenomenological Research, 58, 847-857.

ConeE, E. \& R. FELDMAN (2004) 'Internalism defended', in idem (eds) Evidentialism: Essays in Epistemology (Oxford: Oxford University Press), 53-82.

Feldman, R. (2000) 'The ethics of belief', Philosophy and Phenomenological Research, 6o, 667-695. (2003) Epistemology (Upper Saddle River NJ: Prentice Hall).

Feldman, R. \& E. CONEE (2004) 'Evidentialism', in idem (eds) Evidentialism: Essays in Epistemology (Oxford: Oxford University Press), 83-107.

Foley, R. (1987) The Theory of Epistemic Rationality (Cambridge MA: Harvard University Press)

HASKER, W. (2001) 'The case of the intellectually sophisticated theist', in M. PETERson, W. Hasker,

B. Reichenbach, \& D. Basinger (eds) Philosophy of Religion: Selected Readings, and edn (Oxford: Oxford University Press), 349-355.

JAMES, W. (2003) 'The will to believe', in LouIs P. Pojman (ed.) The Theory of Knowledge: Classical and Contemporary Readings, 3rd edn (Belmont CA: Wadsworth), 518-526.

KierKegaARd, S. (1974) Fear and Trembling and the Sickness unto Death, Walter Lowrie (tr.) (Princeton NJ: Princeton University Press).

Kretzmann, N. (1992) 'Evidence against anti-evidentialism', in K. J. Clark (ed.) Our Knowledge of God (Dordrecht: Kluwer), 17-38.

LONG, T. R. 'Proper function justification and epistemic rationality', Southwest Philosophy Review, (forthcoming). 
Pearsall, J. \& B. Trumble (eds) (1996) The Oxford English Reference Dictionary, and edn (Oxford: Oxford University Press).

PlantingA, A. (1981) 'Is belief in God properly basic?', Nous, 15, 41-51. (1983) 'Reason and belief in God', in A. Plantinga \& N. Wolterstorff (eds) Faith and Rationality (Notre Dame IN: University of Notre Dame Press), 16-93. (1993a) Warrant and Proper Function (Oxford: Oxford University Press). (1993b) Warrant: The Current Debate (Oxford: Oxford University Press). (2000) Warranted Christian Belief (Oxford: Oxford University Press).

QuinN, P. (1985) 'In search of the foundations of theism', Faith and Philosophy, 2, 469-486. (1993) 'The foundations of theism again: a rejoinder to Plantinga', in L. ZAGZEBSKI (ed.), Rational Faith: Catholic Responses to Reformed Epistemology (Notre Dame IN: University of Notre Dame Press), 14-47.

Russell, B. (2002) 'Memory', in M. Huemer (ed.), Epistemology: Contemporary Readings (New York NY: Routledge), 88-90.

SWinBurne, R. (2003) The Resurrection of God Incarnate (Oxford: Oxford University Press). (2004) The Existence of God, 2nd edn (Oxford: Oxford University Press).

Timmons, B. D. (1997) 'More evidence against anti-evidentialism', Dialogue, 39, 62-70.

WYKSTRA, S. J. (1989) 'Toward a sensible evidentialism: on the notion of "needing evidence",', in W. L. RowE $\&$ W. WAinwright (eds) Philosophy of Religion: Selected Readings, nnd edn (New York NY: Harcourt Brace Jovanovich), $426-437$.

\section{Notes}

1. That is, the SEO challenges whether sophisticated Christians have epistemic justification for believing Christian propositions, not whether sophisticates base their Christian beliefs on what yields epistemic justification.

2. The epistemic condition of the sophisticated contemporary religious believer is also a focal point of Quinn (1985), (1993). See also Hasker (2001).

3. I have no precise analysis of the supports relation implied by the evidence-justification principle, but the basic idea is clear enough: if one has, say, more and better evidence indicating the truth of $p$ at time $t$ than one has indicating $\sim p$, then one's total evidence at $t$ supports $p$; and, if one has more and better evidence indicating $\sim p$ at $t$ than one has indicating $p$, then one's total evidence supports $\sim p$ at $t$; and, if one has no more and better evidence indicating $p$ than one has indicating $\sim p$, then one's total evidence supports neither $p$ nor $\sim p$ at $t$.

4. This specification of synchronic propositional justification is consistent with formulations of leading evidentialists. For instance, Richard Feldman: 'The central idea of evidentialism can be stated in the following evidentialist principle about justification: EJ. Believing $\mathrm{p}$ is justified for $\mathrm{S}$ at $\mathrm{t}$ iff $\mathrm{S}$ 's evidence at t supports p'; (2003), 45.

5. Why believe the evidence-justification principle? There are no uncontroversial counter-examples, and one's possessing evidence with respect to a proposition at a time seems to be the best explanation of one's being justified in the epistemic way in believing that proposition at that time; moreover, as Conee (1992) argues, one's possessing evidence is the best explanation of why the epistemic kind of justification is closely related to the truth of what is justified.

6. Mentalism (or 'mind internalism') has two main theses: (1) a supervenience thesis (S): 'The justificatory status of a person's doxastic attitudes strongly supervenes on the person's occurrent and dispositional mental states, events, and conditions'; and (2) a mental duplicates thesis (M) : 'If any two possible individuals are exactly alike mentally, then they are alike justificationally, e.g., the same beliefs are justified for them to the same extent'; Conee and Feldman (2004), 56.

7. The term 'long evidence' (and, by extension, 'long evidentialism') was coined by Steve Wykstra (on the spot) at the 2007 Baylor Philosophy of Religion Conference, to describe my broad and deep construal of evidence.

8. Although beliefs very plausibly count among one's internal mental states, beliefs count as supporting evidence only insofar as the person's reasons for belief, on balance, indicate the truth of the propositions believed. It is plausible that one's believing that $p$ can be evidence for the proposition that one believes that $p$; but, it does not follow, nor is it plausible, that one's belief that $p$ is evidence for $p$. 
9. See Kretzmann (1992). Others, who have argued that Plantinga's anti-evidentialist arguments do not apply to sensible versions of evidentialism, include Alston (1985), Wykstra (1989), and Timmons (1997).

10. Plantinga describes warrant as follows: 'the property enough of which distinguishes knowledge from mere true belief, is a property or quantity had by a belief if and only if ... that belief is produced by cognitive faculties or processes functioning properly in a congenial epistemic environment according to a design plan successfully aimed at truth' (2000), 204.

11. The Freud \& Marx objection amounts to the claim that religious belief is irrational because 'religious belief is not produced by cognitive faculties that are functioning properly and aimed at the truth' (Plantinga (2000), 152) but rather religious belief arises from wishful thinking in the interest of survival, peace of mind, psychological well-being, and the like [Freud] or cognitive dysfunction produced by a perverted social order [Marx].

12. Thus Plantinga concludes: 'There isn't a sensible de jure objection or criticism that is independent of the de facto question. There aren't any de jure criticisms that are sensible when conjoined with the truth of theistic belief; all of them either fail right from the start (as with the claim that it is unjustified to accept theistic belief) or else really presuppose that theism is false'; (Plantinga (2000), 191).

13. Unfortunately, Plantinga does not offer much detail about what properties these terms are supposed to pick out.

14. So, take this paper as my 'homework' (see Plantinga (2000), 104, n. 6o) defending the properness of a de jure objection utilizing a view in the spirit of one of the most popular current theories of justification.

15. For four representative publications spread over three decades, see Plantinga (1981), (1983), (1993b), (2000).

16. See Conee \& Feldman (2004), 61-64. See also the 'Epistemic rationality and blameworthiness' section of this paper.

17. This view is defended by Conee (1998).

18. Compare this to Bertrand Russell's (2002), 88-90 view that a 'feeling of pastness' plays a crucial epistemic role in memory knowledge.

19. Robert Audi speaks to the general nature of this view: 'some foundationalists tend to see experience as a mirror of nature. This seems to some foundationalists a good, if limited, metaphor because it suggests at least two important points: first, that some experiences are produced by external states of the world, somewhat as light produces mirror images; and second, that (normally) the experiences in some way match their causes, for instance in the color and shape one senses in one's visual field'; (Audi (1993), 133).

20. See Long (2010), and idem 'Mentalism vindicated (and a super-blooper problem for proper function justification)' (unpublished), where I argue for a similar point in an objection to Michael Bergmann's (2006) claim that epistemic fittingness is contingent on any cognizer's design plan for belief formation.

21. A referee for this journal called attention to the following view: the experience of seeing a flower triggers the operation of what Plantinga calls the sensus divinitatis, which produces an experience of the presence or greatness of God. On this view, the visual experience of the flower causes - in those whose sensus divinitatis is working properly - an experience indicating the truth of a theistic proposition. I think this view is relevant for what we ultimately ought to think about the SEO, and I intend to treat the issue in a subsequent paper. For now, I'll make two points: First, the view depends on the plausibility of thinking that there is a sensus divinitatis. It is unclear how one might argue for its existence in a non-question-begging way, especially since only a minority of people would be inclined to think that it exists. The problem applied to Christian propositions is harder, since an even smaller minority would be inclined to think that there exists what Plantinga calls 'the internal instigation of the Holy Spirit', which he says is the analogous process that produces Christian beliefs. Second, the plausibility of the view as an objection to the SEO depends on the assumption that the putative defeaters I discuss - in the 'Why the SEO is worthy of philosophical interest' section - are not actual justification defeaters.

22. I thank Justin McBrayer and Kenny Boyce, as well a journal referee, for pushing me to rethink this view.

23. For excellent discussions of this issue, see Conee (1998), and see Conee and Feldman (2004, 64-67).

24. Something along this line is a central theme in Kierkegaard (1974).

25. This view is somewhat suggested by arguments endorsed by William James (2003).

26. Plantinga (2000) is a notable proponent of the first strategy. However, his responses to defeaters depend on some arguments that are irrelevant to long evidentialism and others are not clearly relevant. So, more 
work is needed. Richard Swinburne $(2003 ; 2004)$ is a notable proponent of the second strategy. Although he has provided arguments suggesting what strike me as plausible ways to work toward such a project, much more work is required on many details.

27. In this vein, Plantinga says: 'Many evidentialist objectors argue that theistic belief is irrational because there is insufficient evidence for it; they clearly think being irrational is a bad business; but they seldom say what's bad about it. Instead, they move immediately to the task of showing, as they think, that there is insufficient evidence for belief in God. This prior question, nonetheless, remains crucial: insufficient for what? What is supposed to be bad about believing in the absence of evidence?'; (2000), 86.

28. I am arguing only for the philosophical propriety of an evidentialist objection in light of the fact that it isn't obvious that the total evidence possessed by sophisticated Christians supports Christian propositions.

29. For an excellent discussion of this point, see Feldman (2000), 682-686.

30. In virtue of what is there an intellectual standard of the sort I mention? Candidates include Conee's (1992, 662-663) idea that it exists in virtue of our goal with respect to rational enquiry (i.e., knowing the truth), Feldman's (2000, 676) idea that the standard exists in virtue of our role as believers, Foley's (1987) idea that it exists in virtue of the cognitive goal we have to believe truths and not to believe falsehoods, and Plantinga's (1993a) idea that it exists in virtue of the kind of cognitive beings we are designed to be.

31. This is the first definition of 'rational' in The Oxford English Reference Dictionary. See Pearsall \& Trumble (1996), 1198.

32. For candidate explanations of 'intellectually better', see note 30.

33. Many commentators have argued for this point, including Plantinga (1993b), 24.

34. Another reason to deny that believing against one's evidence makes one deserving of blame concerns the fact that there are various kinds of rationality, including prudential rationality. One and the same belief could satisfy one standard without satisfying another. See Cohen (1984), 279-280; Conee (1992), 658-659; 667-668; and Feldman (2003), 43-45.

35 . William James $(2003,524)$ offers reasons that provide support for this view.

36. William Alston (1991) discusses, in the last chapter, the various grounds for religious belief that I think are salient for providing an adequate rebuttal of the SEO. Nevertheless, it is clear to me that more work needs to be done. Some problems for such a project are raised by various authors in a special edition on the epistemology of religious experience in Faith and Philosophy, 22:4 (October 2005).

37. I thank E. J. Coffman, Timothy McGrew, Alvin Plantinga, Michael Rea, and Stephen Wykstra for helpful comments on early drafts. I also thank Keith Abney, Andrei Buckareff, Earl Conee, Stephen Evans, Richard Feldman, Thomas Flint, Jonathan Kvanvig, Justin McBrayer, Nathan Nobis, Thomas Senor, several referees, as well as participants in the 2007 Baylor Philosophy of Religion Conference, for helpful comments concerning ideas in later drafts. Research for this paper was funded in part by a Postdoctoral Fellowship in The Center for Philosophy of Religion at the University of Notre Dame (2003-2004) and a Junior Faculty Support Grant from the College of Liberal Arts at California Polytechnic State University (2006). 